\title{
Stimulus and mechanisms of exercise-induced bronchoconstriction
}

\section{Educational aims}

1) To describe the stimulus for exercise-induced bronchoconstriction.

1 To describe the different mechanisms whereby this stimulus may act to cause the airways to narrow in asthmatics and athletes.

1 To describe the relevance of the stimulus and mechanism to protocols to diagnose exercise-induced bronchoconstriction.

1 To describe the inflammatory mediators involved in exercise-induced bronchoconstriction.

1 To describe how and why airway injury could contribute to the pathogenesis of airway hyperresponsiveness and exercise-induced bronchoconstriction in athletes.

\section{Summary}

The stimulus for exercise-induced bronchoconstriction (EIB) is the loss of water by humidifying large volumes of air during exercise. The mechanism for EIB relates to the thermal and osmotic effects of water loss. The thermal theory proposes that EIB is a vascular event comprising vasoconstriction during exercise followed by rapid rewarming and a reactive hyperaemia at the end of exercise. The osmotic theory proposes that water loss induces an increase in osmolarity in the airways, which causes the release of mediators that cause bronchial smooth muscle to contract. Increased vascular permeability and leakage are common to both theories.

Exercise-induced bronchoconstriction (EIB)

is the term used to describe the transient increase in airway resistance that follows vigorous exercise [1] that is measured as a reduction in lung function after an exercise test or natural exercise [2]. EIB is diagnosed on the basis of demonstrating a reduction in forced expiratory volume in $1 \mathrm{~s}(\mathrm{FEV} 1)$ of $10-15 \%$ from the preexercise value within 20-30 min of exercise $[3,4]$. EIB is an early manifestation of airway hyperresponsiveness (AHR), usually occurring in childhood, but it may occur for the first time in elite athletes in adulthood [5]. Exercise itself is not necessary to identify EIB and surrogates such as eucapnic voluntary hyperpnoea with dry air are now used to identify potential for EIB [6].

\section{The stimulus for EIB}

Loss of water from the airways as a result of humidifying large volumes of unconditioned air over a short period of time is believed to be the stimulus for EIB. The severity of the airway response is related to the amount of water lost from the airways [7].

Under most climatic conditions, the air needs to be heated and humidified to body conditions before it enters the alveoli. At resting ventilation, most air conditioning is provided by the nasal mucosa. During vigorous exercise, as ventilation increases above $\sim 30 \mathrm{~L}$ per min, there is a switch from nose to mouth breathing and the airways below the pharynx
S.D. Anderson ${ }^{1}$ P. Kippelen ${ }^{2}$

${ }^{1}$ Dept of Respiratory and Sleep Medicine, Royal Prince Alfred Hospital and Sydney Medical School, University of Sydney, Sydney, NSW, Australia. ${ }^{2}$ Centre for Sports Medicine and Human Performance, Brunel University, Uxbridge, UK

\author{
Correspondence \\ S.D. Anderson \\ Dept of Respiratory and Sleep \\ Medicine \\ Royal Prince Alfred Hospital and \\ Sydney Medical School \\ University of Sydney \\ Sydney NSW 2006 \\ Australia \\ sandra.anderson@sydney.edu.au
}

\section{Provenance}

Commissioned article,

peer reviewed.

\section{Competing interest}

S.D. Anderson is a part-time employee of the Sydney South West Area Health Service that owns the patent relating to the use of mannitol (Aridol ${ }^{\mathrm{TM}}$ and Osmohale ${ }^{\mathrm{TM}}$ ) for diagnosing bronchial hyperresponsiveness. S.D. Anderson owns self-funded shares and acts as a consultant to Pharmaxis Ltd and receives a $10 \%$ share of the royalties paid to SSWAHS. 


\section{Figure 1}

Diagram illustrating the thermal (left) and osmotic theory (right) of exercise-induced bronchoconstriction. ASL: airway surface fluid. Modified from [20], with permission from the publisher. are required to complete the conditioning process. Measurements of airway temperature demonstrated that during moderate hyperpnoea, air is still incompletely conditioned at the fifth generation of airways [8].

The immediate source of the water to humidify the air in the lower airways is the sol layer of airway surface liquid (ASL) lining the epithelium, also known as the periciliary fluid layer. Under resting conditions, the epithelium is an absorptive surface but during exercise, it needs to become a secretory surface to replenish the ASL [9]. The first 10 generations of airways have a cumulative surface area of $\sim 742 \mathrm{~cm}^{2}$. Assuming a depth of 5-10 $\mu \mathrm{m}$ (similar to the length of the cilia) for the ASL layer, the volume in the first 10 generations is 0.37-0.74 mL [9]. By generation 12 , the cumulative surface area and volume doubles. The ASL contains sodium, chloride, potassium and calcium ions and has an osmolarity of 290-320 mOsM. When ventilation exceeds 40 $\mathrm{L}$ per min (as occurs in an adult during exercise) water needs to be rapidly replaced on to the airway surface in order to prevent dehydration and an increase in osmolarity. Rapid replacement is achieved by condensation of water back on to the cooled airway surface during expiration. In addition, water moves by osmotic drag from the bronchial circulation through the submucosa and epithelium to the airway surface to restore normal osmolarity. However, mathematical models have estimated that $\sim 40 \%$ of the total water loss per min comes from the lower airways, when ventilating at $60 \mathrm{~L}$ per min under laboratory conditions of $22-26^{\circ} \mathrm{C}$ and $40 \%$ humidity $[10,11]$.

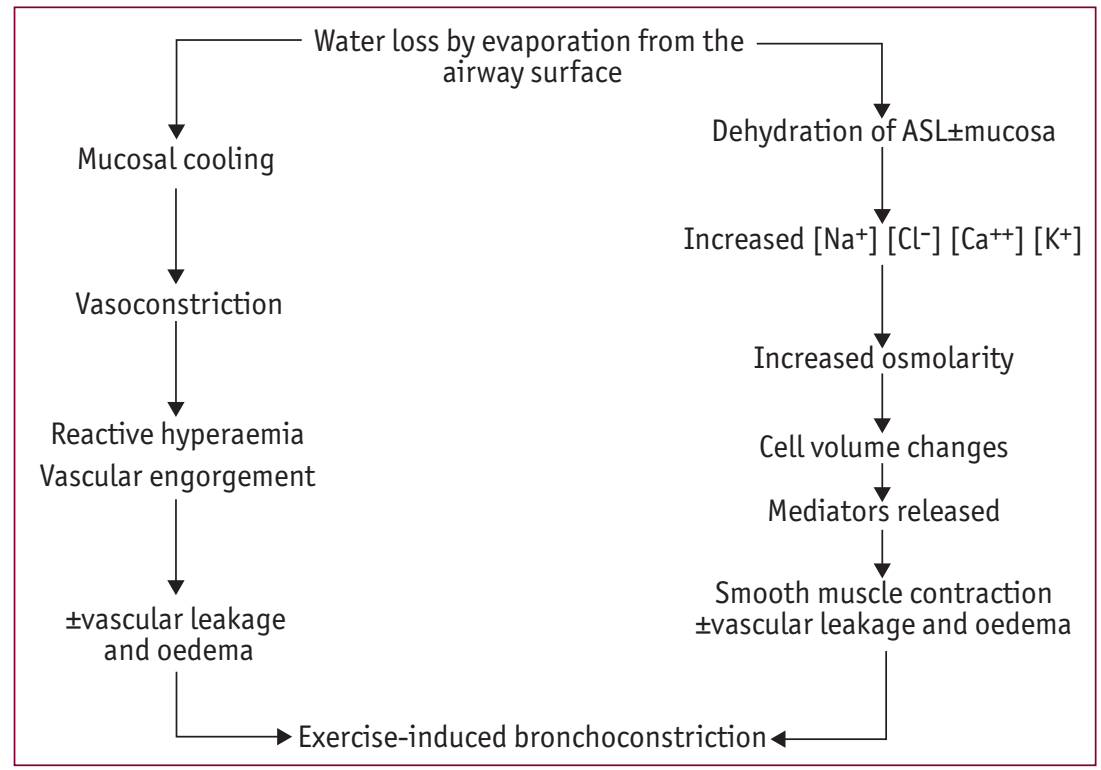




\section{The osmotic theory of EIB}

The thermal theory of EIB does not account for all observations on EIB, particularly under different climatic conditions and for the action of some drugs [19]. For example, severe EIB has been documented in asthmatics breathing hot, dry air $\left(>36^{\circ} \mathrm{C}\right)$ during exercise [22-24]. In contrast, EIB is either markedly inhibited or completely prevented when the inspired air is at body temperature and fully saturated with water $\left(37^{\circ} \mathrm{C}\right.$, $100 \%$ relative humidity or $44 \mathrm{mg} \mathrm{H}_{2} \mathrm{O}$ per $\mathrm{L}$ ) during exercise (fig. 2) [7, 25-27]. These findings demonstrate that abnormal airway cooling and rewarming are not prerequisites for EIB in asthmatic subjects $[22-24,28]$. These and other observations led to the osmotic theory of EIB that proposed that water loss by evaporation leads to a transient increase in the concentration of ions in the ASL with a consequent increase in osmolarity $[7,29]$. The osmotic theory of EIB proposed that the increase in osmolarity, though transient, stimulates the release of mast cell mediators (fig. 1). This was based on observations of histamine release in vitro by human mast cells following a very short ( $<1 \mathrm{~min})$ exposure to hyperosmolar solutions [30]. Secondly, dehydration of the ASL has been demonstrated by the finding of a reduction in mucociliary clearance during dry air hyperpnoea [31]. Mathematical models of respiratory water loss based on experimental data $[11,32]$ would suggest that the transient

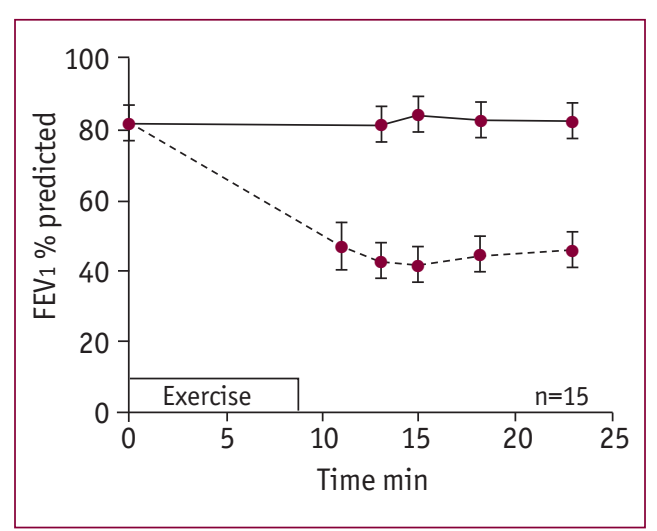

Figure 2

The forced expiratory volume in $1 \mathrm{~s}$ (FEV1) expressed as percentage of predicted in 15 clinically recognised asthmatic subjects (9-42 yrs of age) with exercise-induced bronchoconstriction who exercised for 8 min by running on a treadmill while breathing fully conditioned air $\left(36.5^{\circ} \mathrm{C}, 100 \%\right.$ relative humidity $\left.(\mathrm{RH}) ;-\right)$. A second identical exercise test followed 17-20 mins later, during which the subjects inspired air of temperate conditions $\left(20^{\circ} \mathrm{C}\right.$, $40 \%$ RH; ---). The \% decrease in FEV1 $1 \pm$ D after the first test was $6.5 \pm 5.2 \%$ and after the second, $53.9 \pm 11.5 \%$. Data are taken from [27]. dehydration during exercise also extends to the airway epithelium [33] and the submucosa [19]. Thirdly, experiments using gases of different heat capacities during exercise have confirmed that water loss is more important than heat loss in EIB [34]. Fourthly, a reduction in humidity of the expired air is reported during exercise in warm dry conditions, which is consistent with an increase in osmolarity of the ASL [35]. An increase in ion concentration and osmolarity has been demonstrated in the upper airways following dehydration in humans [36] and the lower airways in animals [37]. Unfortunately, it is technically impossible to document rapid osmotic changes in the ASL because the small volume of fluid is spread over a very large surface area. Furthermore, any measuring device inserted into the human airway would simply increase the water flux to the airway surface.

\section{Relevance of the stimulus and mechanism to protocols to diagnose EIB}

In order to bring about dehydration of the ASL and a transient increase in its osmolarity, the rate of water loss needs to exceed the rate of return in the first 10 generations of airways. This concept is important in considering the appropriateness of protocols used in the laboratory to diagnose EIB. It is generally well recognised that the drier the air inspired and the higher the ventilation sustained during exercise, the less likely a false negative test result will be achieved. However, it is less frequently appreciated that the intensity of the exercise in the first 2 min needs to be sufficient to raise ventilation to $>17.5 * \mathrm{FEV}_{1}(50 \%$ of maximum voluntary ventilation) and the heart rate above $80 \%$ of predicted maximum. This intensity, and preferably a higher one, needs to be sustained for 6 min in young children, and 8 min in adolescents and adults in order to optimise the chance of a positive test $[38,39]$. The target ventilation is easier to achieve during running exercise than cycling, but treadmill running at high speed can present issues of safety.

When the intensity of exercise is rapidly increased, the accompanying ventilation increases and, over a few minutes, more generations of the lower airways are recruited into the conditioning process. The lower the temperature and the drier the inspired air, the more rapidly 


\section{Educational questions}

1. Which of the following are true?

a) Airway cooling is the

stimulus to EIB

b) Water loss is the stimulus

to EIB

c) Airway rewarming is the

stimulus to EIB

d) Respiratory heat loss is

the stimulus to EIB

2. Which of the following is

involved in EIB?

a) The bronchial smooth

muscle only

b) The vascular smooth

muscle only

c) Both the bronchial and

vascular smooth muscle

d) The mucous glands

3. Why are dry air and high ventilation important to provoke EIB?

a) To cause adrenalin release

b) To recruit the greatest sur-

face area into the condition-

ing process

c) To increase bronchial

blood flow

d) To condense more water

on the airway surface

4. Which cell and mediator

plays an important role in

EIB?

a) The neutrophil and

adenosine

b) The epithelial cell and

histamine

c) The mast cell and

prostaglandin $\mathrm{D}_{2}$

d) The basophil and

leukotrienes lower generations will be recruited to condition the air. Decreasing the inspired temperature acts to increase the surface area that is dehydrated. However, increasing the duration of exercise by a few minutes appears to compensate for the effects of lower temperature. For example, the response to dry air hyperpnoea of warm air for $8 \mathrm{~min}$ would be expected to be similar to $4 \mathrm{~min}$ of cold air, provided that the ventilation exceeds 17.5xFEV1 for the warm air [40]. However, any intervention that increases water content of the air inspired, such as nasal breathing [41], use of a mask [42] or an unusually large dead space, will decrease the maximum surface area that can be dehydrated.

If the ventilation increases too slowly, refractoriness to the stimulus at higher ventilations is observed [43]. This is thought to be due to the release of 'protective' mediators that cause relaxation of the bronchial smooth muscle. For example, 20 min warm-up at submaximal intensity or $30 \mathrm{~s}$ repeated sprints cause refractoriness to any vigorous exercise that follows $[44,45]$. There is cross-refractoriness between exercise and hyperosmolar aerosols, implicating a similar mechanism is acting for both stimuli [46].

To overcome many of the technical problems related to optimising the exercise intensity, many laboratories now use the eucapnic voluntary hyperpnoea challenge as a surrogate for exerciseinduced hyperpnoea [47]. This challenge permits target ventilation levels up to $30 \times \mathrm{FEV}_{1}$ to be achieved in the first $30 \mathrm{~s}$ and easily sustained for 6-8 min [48].

Aerosols of hyperosmolar agents, such as $4.5 \%$ saline and mannitol dry powder, have also been used to mimic the dehydrating effects of respiratory water loss on the airway surface osmolarity. In elite summer sport athletes, mannitol has been shown to be a good alternative to eucapnic voluntary hyperpnoea for identifying EIB [49]. In clinical practice, due to the dose response nature of the test and its generally wide availability, mannitol is often preferred over exercise or eucapnic hyperpnoea challenges in those summer athletes with a history of classical asthma and allergies. However, in winter sport athletes, a low prevalence of hyperresponsiveness to mannitol has recently been reported [50].

The reason that recruiting 10 generations of airways into the conditioning process is important in optimising the likelihood of identifying EIB is because that is the largest surface area of the airways that can reasonably become dehydrated and have a transient increase in osmolarity. Beyond this generation, there is an adequate amount of water, so that loss is unlikely to make a significant change in osmolarity. Also, the density of the mast cells increases as the airways get smaller [51]; thus, they are more likely to be close to the airway surface and in a position to be affected by changes in osmolarity [51]. Mast cells are also present on BSM [52] as well as in the submucosa [51].

\section{Role of mediators in EIB}

Mast cells, eosinophils, sensory nerves and epithelial cells are sources of mediators for EIB. The mast cell is considered to be the major source of mediators of bronchoconstriction, such as prostaglandin (PG) $D_{2}$, leukotriene (LT) $C_{4}$ and histamine. Eosinophils are another source of cysteinyl-LTs [53] and sputum eosinophilia is common in EIB [54]. These cell types release mediators in response to hyperosmolarity $[53,55]$. The precise mechanism for this release is unclear, but the rise in intracellular calcium concentration associated with cell volume shrinkage and regulatory volume increase is likely to be important. In addition, neuropeptides are likely to be important in the cough provoked by dry air hyperpnoea in both healthy subjects and those with asthma. This type of cough can be prevented by breathing warm humid air [56].

Another potential mediator in EIB is adenosine arising from adenosine triphosphate (ATP) in the epithelium [57]. Adenosine and ATP are important regulators of the depth of ASL [58] and their concentration is likely to be increased in response to the sheer stress of hyperpnoea of dry air or changes in depth and osmolarity of the ASL [58]. Adenosine has been measured in exhaled breath condensate after exercise and the levels related to the severity of the EIB [59]. It acts on mast cells via $A_{2 b}$ receptors to cause release of mediators. Furthermore, many of the same mediators associated with EIB could act on the vascular smooth muscle to cause leakage and amplify the effects of BSM contraction [20].

For many years, the evidence for the importance of mast cell mediators in EIB was indirect and based on the inhibitory effects of particular drugs on EIB. Any drug that inhibits release of mast cell mediators or prevents the bronchoconstrictor effects, or drugs that reduce the production of mediators or mast cell number, have been shown to have beneficial effects in EIB. Initially, it was the efficacy of sodium cromoglycate (SCG) on EIB that led to the suggestion that mast cells were involved in EIB [60]. SCG inhibits mast cell 
degranulation in vitro [61] and, unlike $\beta_{2}$-agonists, has no relaxing effect on BSM to explain its inhibitory effect in EIB. Some studies have reported that histamine receptor antagonists provide an inhibitory effect on EIB, but the findings are not universal $[62,63]$. The results suggest that histamine is likely to be important in contributing to the severity of the fall in FEV1 immediately after exercise, particularly when the exercise is intense and the smaller airways are involved in the air conditioning process [64]. LT receptor antagonists and 5-lipoxygenase inhibitors reduce the severity of the fall in FEV1 and enhance recovery of FEV 1 to baseline. This suggests that LTs play an important role in sustaining bronchoconstriction following exercise [65]. The failure of any one antagonist to completely inhibit EIB is a reflection of the many mediators involved.

Due to the development of sensitive assays, it is now possible to measure changes in urinary excretion of mediators in response to exercise and other provocative stimuli. The findings from studies using this technique suggest that $\mathrm{PGD}_{2}$ is likely to be the most important mediator of EIB. An increase in the urinary excretion of $9 \alpha, 11 \beta-$ $P G F_{2^{\prime}}$ a metabolite of $\mathrm{PGD}_{2^{\prime}}$ occurs for $\leq 90$ min after exercise and eucapnic voluntary hyperpnoea in asthmatics and athletes with EIB (fig. 3) [66]. This same metabolite has been found in sputum of asthmatics after exercise [67]. There is a significant association between the change in levels of $9 \alpha, 11 \beta-\mathrm{PGF}_{2}$ from baseline and the percentage decrease in FEV 1 after eucapnic hyperpnoea (fig. 4). There is also a sustained increase in urinary excretion of $\mathrm{LTE}_{4}$ following eucapnic voluntary hyperpnoea (fig. 3) but the association with the decrease in FEV1 is weaker [66]. A similar time course of increase in urinary excretion of the metabolites of $\mathrm{PGD}_{2}$ and $\mathrm{LTE}_{4}$ has been measured following a hyperosmolar challenge with mannitol dry powder in humans [68].

\section{Linking the mediator with the airway response}

The increase in urinary excretion of $9 \alpha, 11 \beta-\mathrm{PGF}_{2}$ and $\mathrm{LTE}_{4}$ is inhibited by inhalation of $40 \mathrm{mg} \mathrm{SCC}$ given 15 min before a 6-min eucapnic voluntary hyperpnoea test of dry air in athletes with EIB [69]. A similar finding for inhibition of $9 \alpha, 11 \beta$ $\mathrm{PGF}_{2}$ was made in asthmatics following inhalation of dry powder mannitol after $40 \mathrm{mg}$ SCG or $12 \mu \mathrm{g}$ of the $\beta_{2}$-agonist eformoterol [70]. As these drugs were delivered by inhalation shortly before the challenge, their protective effect is likely to be close to the airway surface. Furthermore, the
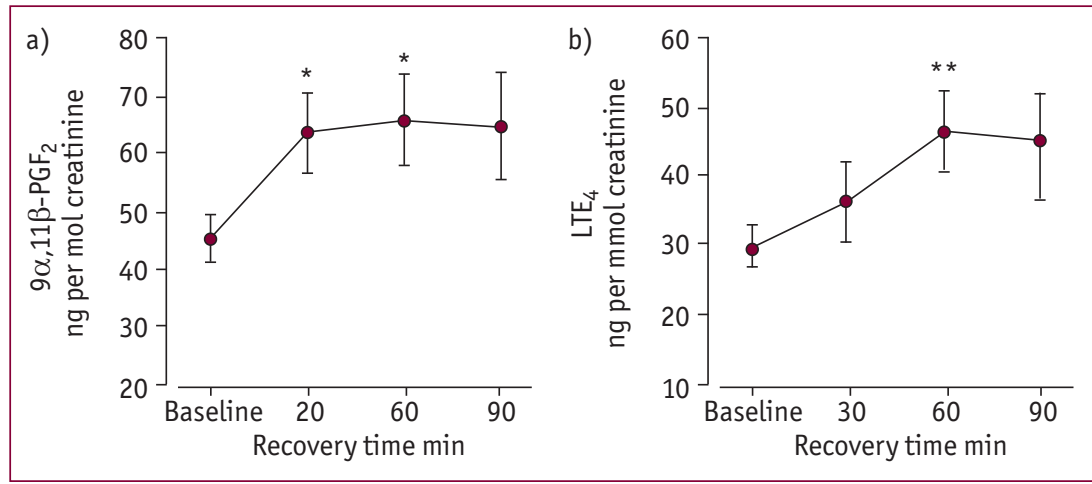

increase in urinary excretion of $9 \alpha, 11 \beta-\mathrm{PGF}_{2}$ could be inhibited by a single 1,500- $\mu \mathrm{g}$ dose of the corticosteroid beclomethasone inhaled 4 $h$ before challenge with eucapnic hyperpnoea [66]. Importantly, the inhibition of the mediators was associated with a reduction in the airway response to these provoking stimuli, supporting a role for them in the mechanism of EIB (fig. 5). When a combination of the histamine antagonist loratadine and the $\mathrm{LT}$ receptor antagonist montelukast was given 36 and $12 \mathrm{~h}$ before exercise, it reduced the concentration in induced sputum of both histamine and cysteinyl-LTs in association with a marked inhibition of the decrease in $\mathrm{FEV}_{1}$ [71]. The beneficial effects of so many drugs in EIB emphasises the importance of withholding times for medication before performing an exercise test or its surrogates.

While it can be argued that SCG and eformoterol prevented release of mast cell mediators by a direct action on mast cells, this is less likely to be the mode of action for beclomethasone. However, there are other modes of action that may explain how beclomethasone and other drugs given acutely can prevent ElB. For example, $\beta_{2}$-agonists may enhance delivery of water to the airway surface and retard dehydration of the ASL by stimulating epithelial chloride ion secretion. By contrast, inhaled beclomethasone may have caused fluid retention in the airway wall by stimulating ion transport to move water in the opposite

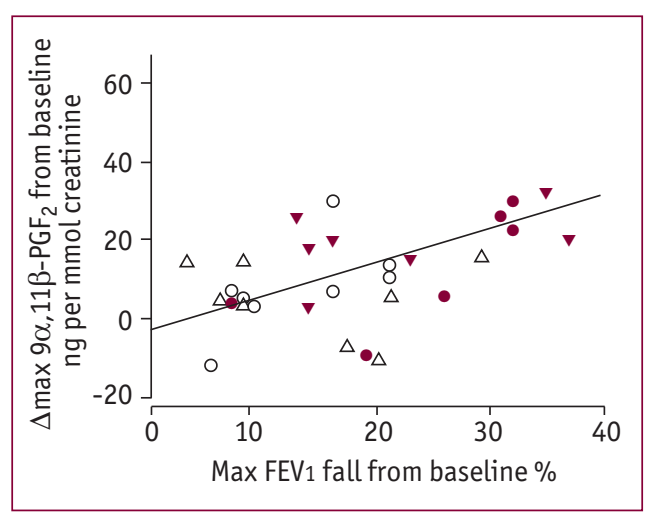

Figure 3

The change in urinary excretion of levels of a) the $P G D_{2}$ metabolite $9 \alpha, 11 \beta-P G F_{2}$ and b) $\mathrm{LTE}_{4}$ over 90 min following 6 min eucapnic voluntary hyperpnoea in eight untrained asthmatics. *: $p<0.05$ versus baseline; ${ }^{* *}: p<0.01$ versus baseline. Modified from [66] with the permission of the publisher.

\section{Figure 4}

The maximum change in urinary excretion of $9 \alpha, 11 \beta-P G F_{2}$ in relation to the maximum \% decrease in FEV1 in asthmatics (triangles) and athletes (circles) after administration of placebo (closed symbols) and 1,500 $\mu \mathrm{g}$ beclomethasone (open symbols). $r=0.544$, $p<0.002$. Modified from [66], with the permission of the publisher. 


\section{Figure 5}

$a$, c) Per cent change in FEV 1 from baseline and $b, d)$ maximum change in $9 \alpha, 11 \beta-P G F_{2}$ in response to 6 min eucapnic voluntary hyperpnoea of dry air $a, b)$ in the presence of placebo (O) and after sodium cromoglycate (SCG; $\boldsymbol{\nabla}$ ) in 11 subjects with $>10 \%$ fall in FEV 1 [69] and $c, d) 4.5 \mathrm{~h}$ after placebo (O) and 1,500 $\mu \mathrm{g}$ beclomethasone (घ) in eight subjects with asthma Modified from [66], with the permission of the publisher.
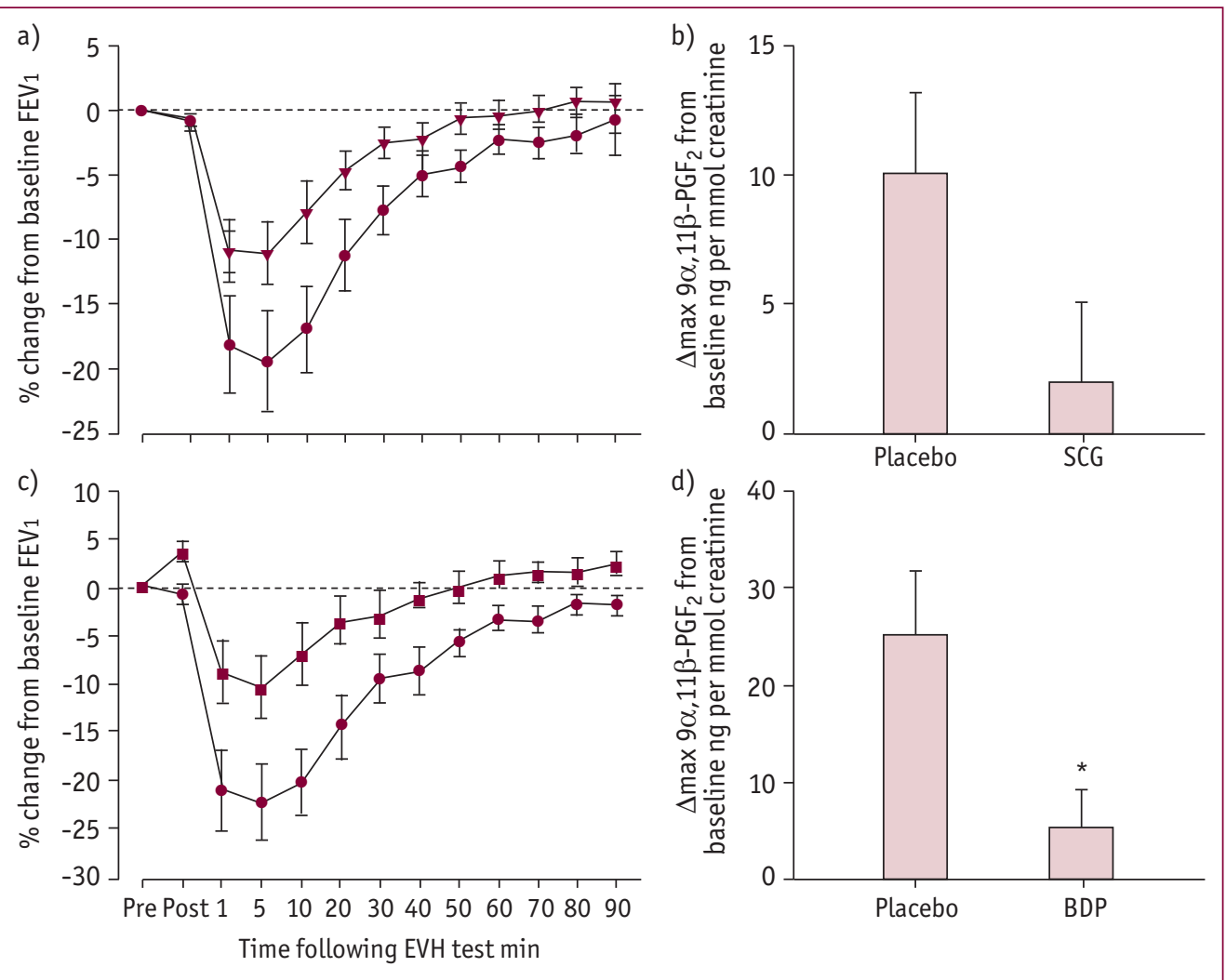

direction. The effect would be to slow the rate of dehydration and change in osmotic environment of the submucosa, such as to be below the threshold for release of mediators [66]. Corticosteroids do not have any recognised inhibitory effect on human mast cell release of mediators. However, a recent study in guinea pigs proposed that steroids inhibit histamine release from mast cells by reducing the rate of the increase in intracellular calcium [72]. It is well known that regular, daily treatment with inhaled corticosteroids reduces severity of EIB [73]. One reason for this is likely to be a reduction in mast cell and eosinophil number with a consequent reduction in concentration of mediators over time of treatment [54]. Inhaled corticosteroids are highly effective for the treatment of EIB. However, for some athletes, e.g. cross-country skiers with "ski asthma" and asthmalike symptoms plus AHR, to methacholine, there may be no clear benefit [74]. The reason may relate to the AHR being the result of repeated injury to the airway epithelium (see below) and linked to a neutrophilic inflammation (rather than the eosinophilic inflammatory phenotype, as found in classical asthma).

For airway narrowing, the BSM needs to be hyperresponsive to the mediators released. However, a state of refractoriness often occurs after EIB and is a common feature associated with all provoking stimuli that act via release of endogenous mediators [75]. Refractoriness occurs in response to a repeated exercise stimulus, lasting for $2-4 \mathrm{~h}$ in $~ 50 \%$ of subjects [76]. This refractoriness is lost following ingestion of a few doses of a nonsteroidal anti-inflammatory agent e.g. indomethacin. Again, this emphasises the importance of medication withholding times and recent history of exercise. One of the mechanisms for refractoriness is thought to involve the bronchodilator $\mathrm{PGE}_{2}[77$ ] that is released in response to hyperpnoea.

In healthy subjects, $\mathrm{PGD}_{2}$ and $\mathrm{LTE}_{4}$ are 100 and 1,000 times as potent as histamine or methacholine in provoking bronchoconstriction, respectively. This difference in potency may be the reason that some children and adults are hyperresponsive to exercise but not to histamine or methacholine $[4,78,79]$. By contrast, other subjects, particularly elite athletes, may be hyperresponsive to histamine or methacholine but not to exercise, eucapnic hyperpnoea, mannitol or adenosine monophosphate [50]. The possibility that AHR may be reflecting airway injury should be considered before a diagnosis of asthma is given to subjects who are hyperresponsive to pharmacological agents but not to stimuli that cause mediator release from inflammatory cells. 


\section{Pathogenesis of AHR and EIB in elite athletes}

Injury of the airways leading to AHR may arise from conditioning large volumes of dry air over long periods of training, with or without exposure to environmental irritants, allergens and viral agents [5]. Epithelial repair quickly follows epithelial injury and the process involves microvascular leak and plasma exudation [80]. Epithelial injury is associated with a reduced capacity to move water to the airway lumen in response to a hyperosmolar stimulus [81]. Thus, repetitive injury may be associated with the need to recruit a larger surface area into the conditioning process, thereby furthering the injury. It has been proposed that AHR develops in elite athletes as a result of changes in the contractile properties of BSM following repeated exposure to plasmaderived products [82]. Airway hyperresponsiveness to methacholine in winter athletes may be a result of these events, particularly in those athletes without EIB or symptoms $[50,83]$. That AHR may result from repetitive airway injury in athletes is supported by documentation of normal responsiveness out of season [84] or after retirement [85]. For summer athletes with atopy and higher immunoglobulin E levels, the hypothesis proposes that passive sensitisation occurs in vivo as a result of the repeated exposure to plasma derived products $[79,83]$. Further studies are required to confirm or refute this hypothesis. However, the hypothesis does serve to explain discordant laboratory findings in response to bronchial provocation in athletes and acts as a starting point for further investigation.

\section{Conclusion}

The stimulus to EIB is likely to be the result of an abnormal burden on the lower airways to provide water for humidification. EIB appears to be an exaggerated response to airway dehydration in the presence of inflammatory cells and mediators in a person with a responsive bronchial and vascular smooth muscle [21]. Knowledge regarding the stimulus and mechanism of EIB should help us all optimise the test conditions in the laboratory and in the field to identify this common cause of airway narrowing.

\section{References}

1. Anderson SD. Exercise-induced asthma. In: Kay AB, ed. Allergy and Allergic Diseases. Oxford, Blackwell Scientific Publications, 1997; pp. 692-711.

2. Carlsen KH, Anderson SD, Bjermer L, et al. Exercise-induced asthma, respiratory and allergic disorders in elite athletes: epidemiology, mechanisms and diagnosis: part I of the report from the Joint Task Force of the European Respiratory Society (ERS) and the European Academy of Allergy and Clinical Immunology (EAACI) in cooperation with GA2LEN. Allergy 2008; 63: 387-403.

3. Sterk PJ, Fabbri LM, Quanjer PH, et al. Airway responsiveness: standardized challenge testing with pharmacological, physical and sensitizing stimuli in adults. Eur Respir J 1993: 6: Suppl. 16, 53-83.

4. Haby MM, Anderson SD, Peat JK, et al. An exercise challenge protocol for epidemiological studies of asthma in children: comparison with histamine challenge. Eur Respir J 1994; 7: 43-49.

5. Fitch KD, Sue-Chu M, Anderson SD, et al. Asthma and the elite athlete: summary of the International Olympic Committee's Consensus Conference, Lausanne, Switzerland, January 22-24, 2008. J Allergy Clin Immunol 2008; 122: 254-260.

6. Rundell KW, Slee JB. Exercise and other indirect challenges to demonstrate asthma or exercise-induced bronchoconstriction in athletes. J Allergy Clin Immunol 2008; 122: 238-246.

7. Anderson SD, Schoeffel RE, Follet R, et al. Sensitivity to heat and water loss at rest and during exercise in asthmatic patients. Eur J Respir Dis 1982; 63: 459-471.

8. McFadden ER Jr, Pichurko BM, Bowman HF, et al. Thermal mapping of the airways in humans. J Appl Physiol 1985; 58: 564-570.

9. Anderson SD. Asthma provoked by exercise, hyperventilation, and the inhalation of non-isotonic aerosols. In: Barnes PJ, Rodger IW, Thomson NC, eds. Asthma: Basic Mechanisms and Clinical Management. 2nd Edn. London, Academic Press, 1992; pp. 473-490.

10. Anderson SD, Daviskas E. Pathophysiology of exercise-induced asthma: role of respiratory water loss. In: Weiler J, ed. Allergic and Respiratory Disease in Sports Medicine. New York, Marcel Dekker, 1997; pp. 87-114.

11. Daviskas E, Gonda I, Anderson SD. Local airway heat and water vapour losses. Respir Physiol 1991; 84: 115-132.

12. McFadden ER, Pichurko BM. Intraairway thermal profiles during exercise and hyperventilation in normal man. $J$ Clin Invest 1985; 76: 1007-1010.

13. McFadden ER, Lenner KA, Strohl KP. Postexertional airway rewarming and thermally induced asthma. J Clin Invest 1986; 78: 18-25.

14. Gilbert IA, Fouke JM, McFadden ER. Heat and water flux in the intrathoracic airways and exercise-induced asthma. $J$ Appl Physiol 1987; 63: 1681-1691.

15. McFadden ER. Hypothesis: exercise-induced asthma as a vascular phenomenon. Lancet 1990; 1:880-883.

16. Gilbert IA, Fouke JM, McFadden ER Jr. The effect of repetitive exercise on airway temperatures. Am Rev Respir Dis 1990; 142: 826-831.

17. Gilbert IA, Regnard J, Lenner KA, et al. Intrathoracic airstream temperatures during acute expansions of thoracic blood volume. Clin Sci 1991; 81: 655-661. 
18. Gilbert IA, Winslow CJ, Lenner KA, et al. Vascular volume expansion and thermally induced asthma. Eur Respir J 1993; 6: 189-197.

19. Anderson SD, Daviskas E. The airway microvasculature and exercise-induced asthma. Thorax 1992; 47: 748-752.

20. Anderson SD, Holzer K. Exercise-induced asthma: is it the right diagnosis in elite athletes? J Allergy Clin Immunol 2000; 106: 419-428.

21. Anderson SD, Daviskas E. The mechanism of exercise-induced asthma is... J Allergy Clin Immunol 2000; 106: 453-459.

22. Hahn A, Anderson SD, Morton AR, et al. A re-interpretation of the effect of temperature and water content of the inspired air in exercise-induced asthma. Am Rev Respir Dis 1984: 130: 575-579.

23. Anderson SD, Schoeffel RE, Black JL, et al. Airway cooling as the stimulus to exercise-induced asthma - a reevaluation. Eur J Respir Dis 1985; 67: 20-30.

24. Aitken ML, Marini JJ. Effect of heat delivery and extraction on airway conductance in normal and in asthmatic subjects. Am Rev Respir Dis 1985; 131: 357-361.

25. Bar-Or 0, Neuman I, Dotan R. Effects of dry and humid climates on exercise-induced asthma in children and preadolescents. J Allergy Clin Immunol 1977; 60: 163-168.

26. Strauss RH, McFadden ER, Ingram RH, et al. Influence of heat and humidity on the airway obstruction induced by exercise in asthma. J Clin Invest 1978; 61: 433-440.

27. Anderson SD, Daviskas E, Schoeffel RE, et al. Prevention of severe exercise-induced asthma with hot humid air. Lancet 1979; 2: 629.

28. Smith CM, Anderson SD, Walsh S, et al. An investigation of the effects of heat and water exchange in the recovery period after exercise in children with asthma. Am Rev Respir Dis 1989; 140: 598-605.

29. Anderson SD. Is there a unifying hypothesis for exercise-induced asthma? J Allergy Clin Immunol 1984; 73: 660-665.

30. Eggleston PA, Kagey-Sobotka A, Schleimer RP, et al. Interaction between hyperosmolar and IgE-mediated histamine release from basophils and mast cells. Am Rev Respir Dis 1984; 130: 86-91.

31. Daviskas E, Anderson SD, Gonda I, et al. Changes in mucociliary clearance during and after isocapnic hyperventilation in asthmatic and healthy subjects. Eur Respir J 1995; 8: 742-751.

32. Daviskas E, Gonda I, Anderson SD. Mathematical modelling of the heat and water transport in the human respiratory tract. J Appl Physiol 1990; 69: 362-372.

33. Anderson SD, Daviskas E, Smith CM. Exercise-induced asthma: a difference in opinion regarding the stimulus. Allergy Proc 1989; 10: 215-226.

34. Argyros GJ, Phillips YY, Rayburn DB, et al. Water loss without heat flux in exercise-induced bronchospasm. Am Rev Respir Dis 1993; 147: 1419-1424.

35. Tabka Z, Ben Jebria A, Vergeret J, Guenard H. Effect of dry warm air on respiratory water loss in children with exercise-induced asthma. Chest 1988; 94: 81-86.

36. Togias AG, Proud D, Lichenstein LM, et al. The osmolality of nasal secretions increases when inflammatory mediators are released in response to inhalation of cold, dry air. Am Rev Respir Dis 1988; 137: 625-629.

37. Freed AN, Davis MS. Hyperventilation with dry air increases airway surface fluid osmolality in canine peripheral airways. Am J Respir Crit Care Med 1999; 159: 1101-1107.

38. Carlsen KH, Engh G, Mørk M. Exercise induced bronchoconstriction depends on exercise load. Respir Med 2000; 94: 750-755.

39. Anderson SD, Charlton B, Weiler JM, et al. A305 Study Group: comparison of mannitol and methacholine to predict exercise-induced bronchoconstriction and a clinical diagnosis of asthma. Respir Res 2009; 10: 4.

40. McFadden ER, Nelson JA, Skowronski ME, et al. Thermally induced asthma and airway drying. Am J Respir Crit Care Med 1999; 160: 221-226.

41. Shturman-Ellstein R, Zeballos RJ, Buckley JM, et al. The beneficial effect of nasal breathing on exercise-induced bronchoconstriction. Am Rev Respir Dis 1978; 118: 65-73.

42. Millqvist $\mathrm{E}, \mathrm{Bake} \mathrm{B}, \mathrm{Bengtss}$ on $\mathrm{U}$, et al. A breathing filter exchanging heat and moisture prevents asthma induced by cold air. Allergy 1995; 50: 225-228.

43. Argyros GJ, Roach JM, Hurwitz KM, et al. The refractory period after eucapnic voluntary hyperventilation challenge and its effect on challenge technique. Chest 1995; 108: 419-424.

44. Reiff DB, Choudry NB, Pride NB, et al. The effect of prolonged submaximal warm-up exercise on exercise-induced asthma. Am Rev Respir Dis 1989; 139: 479-484.

45. Schnall RP, Landau LI. Protective effects of repeated short sprints in exercise-induced asthma. Thorax 1980; 35 : 828-832.

46. Belcher NG, Rees PJ, Clark TJM, et al. A comparison of the refactory periods induced by hypertonic airway challenge and exercise in bronchial asthma. Am Rev Respir Dis 1987; 135: 822-825.

47. Anderson SD, Argyros GJ, Magnussen H, et al. Provocation by eucapnic voluntary hyperpnoea to identify exercise induced bronchoconstriction. BrJ Sports Med 2001; 35: 344-347.

48. Rundell KW, Anderson SD, Spiering BA, et al. Field exercise vs laboratory eucapnic voluntary hyperventilation to identify airway hyperresponsiveness in elite cold weather athletes. Chest 2004; 125: 909-915.

49. Holzer K, Anderson SD, Chan H-K, et al. Mannitol as a challenge test to identify exercise-induced bronchoconstriction in elite athletes. Am J Respir Crit Care Med 2003; 167: 534-547.

50. Sue-Chu M, Brannan JD, Anderson SD, et al. Airway hyperresponsiveness to methacholine, adenosine 5-monophosphate, mannitol, eucapnic voluntary hyperpnoea and field exercise challenge in elite cross country skiers. Brit J Sports Med 2010; [Epub ahead of print DOI: 10.1136/bjsm.2009.071043].

51. Carroll NG, Mutavdzic S, James AL. Distribution and degranulation of airway mast cells in normal and asthmatic subjects. Eur Respir J 2002; 19: 879-885.

52. Bradding P, Walls AF, Holgate ST. The role of the mast cell in the pathophysiology of asthma. J Allergy Clin Immunol 2006; 117: 1277-1284.

53. Moloney ED, Griffin S, Burke CM, et al. Release of inflammatory mediators from eosinophils following a hyperosmolar stimulus. Respir Med 2003; 97: 1-5.

54. Duong M, Subbarao P, Adelroth E, et al. Sputum Eosinophils and the response of exercise-induced bronchoconstriction to corticosteroid in asthma. Chest 2008; 133: 404-411.

55. Gulliksson M, Palmberg L, Nilsson $G$, et al. Release of prostaglandin $D_{2}$ and leukotriene $C_{4}$ in response to hyperosmolar stimulation of mast cells. Allergy 2006; 61: 1473-1479. 
56. Banner AS, Green J, O'Connor M. Relation of respiratory water loss to coughing after exercise. N Engl J Med 1984; 311: 883-886.

57. Anderson SD. How does exercise cause asthma attacks? Curr Opin Allergy Clin Immunol 2006; 6: 37-42.

58. Lazarowski ER, Tarran R, Grubb BR, et al. Nucleotide release provides a mechanism for airway surface liquid homeostasis. J Biol Chem 2004; 279: 36855-36864.

59. Csoma Z, Huszar E, Vizi E, et al. Adenosine level in exhaled breath increases during exercise-induced bronchoconstriction. Eur Respir J 2005; 25: 873-878.

60. Silverman M, Andrea T. Time course of effect of disodium cromoglycate on exercise-induced asthma. Arch Dis Childh 1972; 47: 419-422.

61. Leung KB, Flint KC, Brostoff J, et al. A comparison of nedocromil sodium and sodium cromoglycate on human lung mast cells obtained by bronchoalveolar lavage and by dispersion of lung fragments. Eur J Respir Dis Suppl 1986; 147: 223-226.

62. Baki A, Orhan F. The effect of loratadine in exercise-induced asthma. Arch Dis Childh 2002; 86: 38-39.

63. Dahlén B, Roquet A, Inman MD, et al. Influence of zafirlukast and loratadine on exercise-induced bronchoconstriction. J Allergy Clin Immunol 2002; 109: 789-793.

64. Anderson SD, Brannan JD. Exercise induced asthma: is there still a case for histamine? J Allergy Clin Immunol 2002; 109: 771-773.

65. Kemp JP, Dockhorn RJ, Shapiro GG, et al. Montelukast once daily inhibits exercise-induced bronchoconstriction in 6- to 14-year-old children with asthma. J Pediatr 1998; 133: 424-428.

66. Kippelen P, Larsson J, Anderson SD, et al. Acute effects of beclomethasone on hyperpnoea-induced bronchoconstriction. Med Sci Sports Exerc 2010; 42: 273-280.

67. Haverkamp HC, Dempsey JA, Miller JD, et al. Gas exchange during exercise in habitually active asthmatic subjects. J Appl Physiol 2005; 99: 1938-1950.

68. Brannan JD, Gulliksson M, Anderson SD, et al. Evidence of mast cell activation and leukotriene release after mannitol inhalation. Eur Respir J 2003; 22: 491-496.

69. Kippelen P, Larsson J, Anderson SD, et al. Effect of sodium cromoglycate on mast cell mediators during hyperpnea in athletes. Med Sci Sports Exerc 2010; Epub ahead of print D0I: 10.1249/MSS.0b013e3181da4f7d].

70. Brannan JD, Gulliksson M, Anderson SD, et al. Inhibition of mast cell $\mathrm{PGD}_{2}$ release protects against mannitolinduced airway narrowing. Eur Respir J 2006; 27: 944-950.

71. Hallstrand TS, Moody MW, Wurfel MM, et al. Inflammatory basis of exercise-induced bronchoconstriction. Am J Respir Crit Care Med 2005; 172: 679-686.

72. Zhou J, Lui DF, Liu C, et al. Glucocorticoids inhibit degranulation of mast cells in allergic asthma via nongenomic mechanism. Allergy 2008; 63: 1177-1185.

73. Subbarao P, Duong M, Adelroth E, et al. Effect of ciclesonide dose and duration of therapy on exercise-induced bronchoconstriction in patients with asthma. J Allergy Clin Immunol 2006; 117: 1008-1013.

74. Sue-Chu M, Karjalainen E-M, Laitinen A, et al. Placebo-controlled study of inhaled budesonide on indices of airways inflammation in bronchoalveolar lavage fluid and bronchial biopsies in cross country skiers. Respiration 2000; 67: 417-425.

75. Joos GF, O'Connor B, Anderson SD, et al. Indirect airway challenges. Eur Respir J 2003; 21: 1050-1068.

76. Edmunds A, Tooley M, Godfrey S. The refractory period after exercise-induced asthma: its duration and relation to the severity of exercise. Am Rev Respir Dis 1978; 117: 247-254.

77. Wilson BA, Bar-Or 0, $0^{\prime}$ Byrne PM. The effects of indomethacin on refractoriness following exercise both with and without bronchoconstriction. Eur Respir J 1994; 12: 2174-2178.

78. Backer V, Dirksen A, Bach-Mortensen N, et al. The distribution of bronchial responsiveness to histamine and exercise in 527 children and adolescents. J Allergy Clin Immunol 1991; 88: 68-76.

79. Holzer K, Anderson SD, Douglass J. Exercise in elite summer athletes: challenges for diagnosis. J Allergy Clin Immunol 2002; 110: 374-380.

80. Persson CG, Erjefalt JS, Greiff L, et al. Plasma-derived proteins in airway defence, disease and repair of epithelial injury. Eur Respir J 1998; 11: 958-970.

81. Wells UM, Woods AJ, Hanafi Z, et al. Tracheal epithelial damage alters tracer fluxes and effects of tracheal osmolality in sheep in vivo. J Appl Physiol 1995; 78: 1921-1930.

82. Anderson SD, Kippelen P. Airway injury as a mechanism for exercise-induced bronchoconstriction in elite athletes. J Allergy Clin Immunol 2008; 122: 225-235.

83. Stensrud T, Mykland KV, Gabrielsen K, et al. Bronchial hyperresponsiveness in skiers: field test versus methacholine provocation? Med Sci Sports Exerc 2007; 39: 1681-1686.

84. Hemingson HB, Davis BE, Cockcroft DW. Seasonal fluctuations in airway responsiveness in elite endurance athletes. Can Respir J 2004; 11: 399-401.

85. Helenius I, Rytilä P, Sarna S, et al. Effect of continuing or finishing high-level sports on airway inflammation, bronchial hyperresponsiveness, and asthma: a 5-year prospective follow-up study of 42 highly trained swimmers. J Allergy Clin Immunol 2002; 109: 962-968. 